\title{
Effects of Nitrogen Rate and Cover Crop on Cotton (Gossypium hirsutum L.) Yield and Soil Water Content
}

\author{
Ruixiu Sui * and Saseendran S. Anapalli \\ USDA, Agricultural Research Service, Sustainable Water Management Research Unit, 141 Experiment Station \\ Road, Stoneville, MS 38776, USA; saseendran.anapalli@usda.gov \\ * Correspondence: ruixiu.sui@usda.gov
}

Citation: Sui, R.; Anapalli, S.S. Effects of Nitrogen Rate and Cover Crop on Cotton (Gossypium hirsutum L.) Yield and Soil Water Content. Agriculture 2021, 11, 650. https:/ / doi.org/10.3390/agriculture11070650

Academic Editor: Mariko Shimizu

Received: 8 June 2021

Accepted: 8 July 2021

Published: 10 July 2021

Publisher's Note: MDPI stays neutral with regard to jurisdictional claims in published maps and institutional affiliations.

Copyright: (c) 2021 by the authors. Licensee MDPI, Basel, Switzerland. This article is an open access article distributed under the terms and conditions of the Creative Commons Attribution (CC BY) license (https:// creativecommons.org/licenses/by/ $4.0 /)$.

\begin{abstract}
The objective of this study was to test the effects of $\mathrm{N}$ rates and tillage radish (Raphanus sativus var. longipinnatus) cover crop (TRCC) on soil water and cotton (Gossypium hirsutum L.) yield. In three years of the investigation, the treatments were $\mathrm{N}$ rates at $84 \mathrm{~kg} \mathrm{ha}^{-1}$ and $140 \mathrm{~kg} \mathrm{ha}^{-1}$ with and without TRCC. Soil water contents were measured using soil water sensors. Results showed that cotton yield was not significantly $(p>0.05)$ influenced by TRCC. Compared to $\mathrm{N}$ rate at $84 \mathrm{~kg} \mathrm{ha}^{-1}, 140 \mathrm{~kg} \mathrm{~N} \mathrm{ha}^{-1}$ increased lint yield by $2.0 \%, 7.4 \%, 18.4 \%$ in 2017, 2018, and 2019, respectively, but the increase was significant only in $2019(p<0.02)$. Interactions between TRCC and nitrogen rate on yield were significant $(p<0.03)$ only in 2017. TRCC increased soil water infiltration capacity, resulting in higher soil water content. Use of TRCC did not affect the cotton yield, which could be due to the high inputs of water and high rates of $\mathrm{N}$ neutralizing the positive contributions to the cotton growth expected from the TRCC. Sub-optimum winter temperatures hampered the establishment and subsequent growth of TRCC, which also possibly contributed to its minimum impacts on cotton crop performance in the following season.
\end{abstract}

Keywords: cotton; nitrogen; tillage radish; cover crop; yield

\section{Introduction}

The United States of America, the largest cotton exporter, accounting for one-third of global trade in raw cotton, is the third largest cotton producer in the world [1]. The U.S. cotton is grown in a region known as the Cotton Belt in the Southern United States, including the State of Mississippi. Mississippi producers planted approximately 287,000 hectares of cotton in 2019 in Mississippi, which make Mississippi the third largest state in the United State in cotton production [1]. Most of the cotton produced in the State of Mississippi is grown in the Mississippi Delta (MD).

Nitrogen $(\mathrm{N})$ fertilization in cotton has a critical effect on cotton yield [2,3]. Both under-use and over-use of $\mathrm{N}$ fertilizer can create a negative effect on the desired growth pattern of cotton plants and compromise yield [4-6]. A $\mathrm{N}$ deficiency can cause poor vegetative growth, fruit shedding, and small bolls resulting in low yield [7]. But $\mathrm{N}$ in excess of the cotton plant demands can induce excessive vegetative growth, increase pest problems, delay maturity, and ultimately reduce the crop yield [8-10]. Most of $\mathrm{N}$ fertilizer in cotton production is applied by broadcasting on the soil surface or directly injecting into the soil. Soil physical, chemical, and biological properties and climatic conditions could influence $\mathrm{N}$ cycling processes in the soil and further affect the cotton growth response to $\mathrm{N}$ fertilization [5]. Due to the complexity of interactions among the chemical, physical, and biological factors in soil-N cycling processes, it is very difficult to accurately predict $\mathrm{N}$ application requirements of cotton crops $[5,11]$. Consequently, researchers have been continuously investigating the crop response to $\mathrm{N}$ rate for optimal $\mathrm{N}$-use efficiency in cotton production systems [12].

In the MD region, mean annual precipitation is about $130 \mathrm{~cm}$. About $70 \%$ of the precipitation is received during the crop-fallow months of September through March, 
but the staple crops (soybean, cotton, corn, and rice) are summer grown (April-August). Traditionally, for controlling weeds and avoiding heavy rainfalls in April/May, tillage operations are performed following harvest in the fall season [13]. This practice makes the soil vulnerable to water and wind erosion during the fallow months, modifying rainwater infiltration, runoff, and deep percolation processes and culminating in poor rainwater use efficiency in cropping systems, which leads to more irrigation water withdrawal from the shallow Mississippi River Valley Alluvial Aquifer underlying this region [14].

Depending on the amount and distribution of the rainfall events, cover crops during the fallow season can improve water infiltration and reduce runoff losses of the rainwater received [15-18]. Fallow season-long cover crops can also improve crop yields and be beneficial for soil health [19]. Water extraction by the cover crops, however, can also limit the water left in the soil for the subsequent crop, especially in water limited areas. But, in the humid climate of the MD characterized by heavy rainfalls during the winter-cropfallow season, unlike in the arid and semiarid climates, the water used by the cover crops normally does not affect the water availability to summer crops that follow.

Tillage radish (Raphanus sativus var. longipinnatus) has been adopted as a cover crop by farmers for over a decade in the United States. The large and deep taproot of this crop can penetrate compacted soil layers by "bio-drilling" the crop root zone, which increases water infiltration into the soil, reduces surface runoff, and supports the subsequent crop by obtaining water and nutrient from deep soils $[20,21]$. Because of its robust rooting system and rapid growth characteristics, tillage radish cover crop (TRCC) can scavenge for the residual $\mathrm{N}$, deeper than normal, in the soil, which can reduce excess $\mathrm{N}$ leaching into the groundwater [20].

In the MD, heavy rainfall events occur frequently, causing extensive amounts of runoff water loss from croplands. Excessive surface runoff is often associated with lower rainwater infiltration into the soil for crop use and excessive nutrients leached out of the cropped areas leading to water-soil-environmental quality degradations [22-24]. Optimizing N application rates and minimizing excess $\mathrm{N}$ leaching from crop production systems can help maximize farm profits and minimize environmental impacts. The objective of this study is to assess interacting effects of $\mathrm{N}$ rates and TRCC system on cotton yield and soil water in the humid climate of the MD.

\section{Materials and Methods}

\subsection{Experimental Site Description}

Field studies were conducted from 2017 to 2019 in a USDA-ARS research farm at Stoneville, MS. The farm is located about $15 \mathrm{~km}$ east of the Mississippi River in the MD region. The field was approximately 5 ha in rectangular shape $\left(183 \times 276 \mathrm{~m}^{2}\right)$ with an approximately $0.5 \%$ slope from the east to the west and constituted one-half of the area under a center pivot irrigation system installed at the site for sprinkler irrigations. A weather station was located at the west edge of the field, outside the center pivot sprinkler reach. According to the USDA NRCS soil survey [25], predominant soil map unit in the field was Commerce very fine sandy loam (Cn; fine-silty, mixed, superactive, nonacid, thermic Fluvaquentic Endoaquepts). Smaller areas of Commerce silty clay loam (Ch; finesilty, mixed, superactive, nonacid, thermic Fluvaquentic Endoaquepts) and Bosket very fine sandy soils (Be; Fine-loamy, mixed, active, thermic Mollic Hapludalfs) were located in the southwest and northwest corners, and southeast corner of the field, respectively.

Twelve plots were laid out in the field (Figure 1). Plots were $183 \mathrm{~m}$ long, $23 \mathrm{~m}$ wide, each with 24 rows spaced at $0.97 \mathrm{~m}$. A 7.7-m wide buffer was used between the plots. A $2 \times 2$ factorial experiment in randomized complete block design (RCBD) with three replications was used to test the effect of two $\mathrm{N}$ application rates $\left(84 \mathrm{~kg} \mathrm{ha}^{-1}\right.$ and $140 \mathrm{~kg} \mathrm{ha}^{-1}$ ) with cover crop (CC) and with no cover crop (NCC) on cotton yield. The four treatments CC $\times$ N84 $\left(84 \mathrm{~kg} \mathrm{ha}^{-1} \mathrm{~N}\right.$ rate with CC), NCC $\times \mathrm{N} 84\left(84 \mathrm{~kg} \mathrm{ha}^{-1} \mathrm{~N}\right.$ rate with no cover crop), CC $\times$ N140 $\left(140 \mathrm{~kg} \mathrm{ha}^{-1} \mathrm{~N}\right.$ rate with CC $)$, and NCC $\times \mathrm{N} 140\left(140 \mathrm{~kg} \mathrm{ha}^{-1} \mathrm{~N}\right.$ 
rate with no cover crop) were randomly assigned to each of the three blocks to give a total of 12 plots in the test.

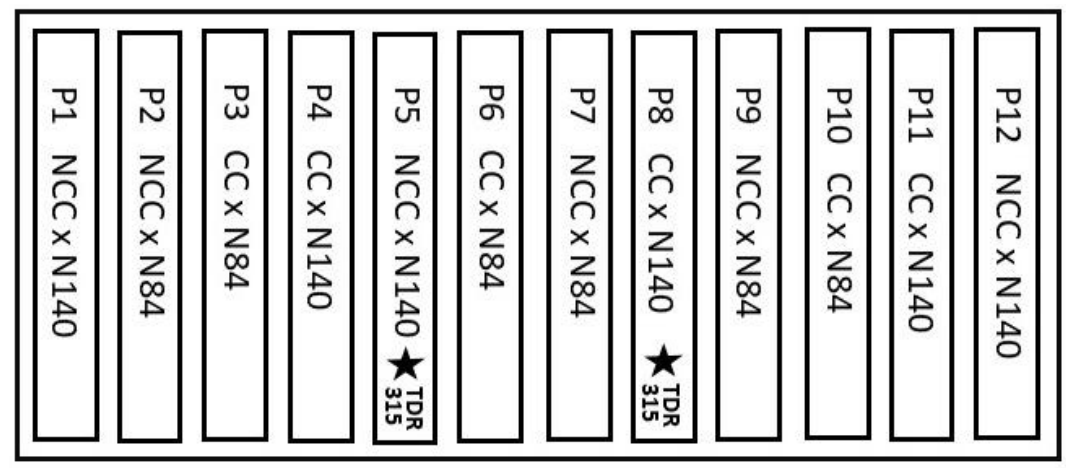

Figure 1. Experimental plot layout with RCBD; Block 1 (P1-P4); Block 2 (P5-P8); Block 3 (P9-P12). Soil water sensing devices (TDR-315) were installed in P5 and P8 for measuring soil volumetric water content. Associated with each soil water sensing system in P5 and P8, four soil water sensors (TDR 315) were installed at depths of $15,30,46$, and $61 \mathrm{~cm}$.

\subsection{Crop Management}

The field study was conducted for three consecutive crop years from 2017 to 2019 . After cotton was harvested each year, cotton stalks were shredded using a rotary shredder. Then the tillage radish cover crop (TRCC) was planted at a seeding rate of $9 \mathrm{~kg} \mathrm{ha}^{-1} \mathrm{using}$ a seed drill. In the fall 2016 (the winter cover crop season before the first cotton crop in 2017), the cover crop was sowed on 12 October and $25 \mathrm{~mm}$ water was applied after planting. However, due to the unusual dry weather, the seeds did not geminate well. The TRCC was replanted on 20 October and $19 \mathrm{~mm}$ water was applied for gemination. The CC was terminated on 17 March 2017. For 2018 cotton season, the TRCC was planted on 27 October 2017 and terminated on 22 March 2018. In 2017 and 2018, the cover crop was terminated by applying glyphosate herbicide and using minimum-tillage practice which lightly disked the soil to chop cover crop residue, followed by forming the rows for planting. In the 2019 cotton season, the TRCC was planted on 25 October 2018. The TRCC was killed by the colder than typical winter weather, so no herbicide was sprayed for cover crop termination in 2019. In all three years, no nitrogen fertilizer was applied to the cover crop.

Cotton variety FM1944GLB2 was planted in 2017 and 2018 seasons, and the variety ST4848GLT in 2019. Because the variety FM1944GLB2 was not available in our cottonseed vendor in 2019, we chose the variety ST4848GLT for planting in that year as its field trials reported near identical agronomic performance related to lint yield and lint value (https:/ / wharton.agrilife.org/2018/12/11/2018-replicated-agronomic-cottonevaluation-race-south-east-and-central-regions-of-texas / accessed on: 9 July 2021). The planting dates were on 9 May 2017, 10 May 2018, and 17 May 2019. The seeding rate was approximately 11.3 seeds $\mathrm{m}^{-2}$ on raised beds in a furrow-ridge system with $0.97 \mathrm{~m}$ row spacing. $\mathrm{N}$ fertilizer was applied as a urea-ammonium nitrate solution $(\mathrm{N}-\mathrm{sol}, 32 \% \mathrm{~N})$ to the plots at 23 days after planting (DAP) in 2017, 52 DAP in 2018, and 55 DAP in 2019. A professional consultant was hired to work on the insect and weed control of the study field. Based on the recommended insect and weed control guidelines for Mississippi [26-28], the consultant regularly assessed the insect and weed situation in the study field and cooperated with our technicians to promptly apply insecticides and herbicides as needed. In general, insects and weeds in the study field were well controlled for all three seasons.

In 2017, cotton canopy defoliation was initiated on 12 September. Central rows of each plot were harvested for determining the yield on 3 October. In 2018, the cotton was defoliated twice. The first defoliation was on 14 September and the second on 28 September. Cotton in the central rows of each plot was picked on 11 October followed by planting the cover crop on 25 October. In 2019, the defoliation was conducted on 20 September. Because of the wet weather, cotton harvest was delayed until 18 November. Same as the previous 
two years, the central 8 rows in each plot were picked for yield. The TRCC was planted on 21 November. In all three years, the cotton was picked using a CASE IH spindle-type cotton harvester.

\subsection{Soil Water}

A Valley 8000 center pivot (Valmont Irrigation, Valley, NE, USA) irrigation system was employed for irrigation. The system was configured in four spans with a total length of $233 \mathrm{~m}$. The distance from the sprinklers to the ground surface was approximately $1.83 \mathrm{~m}$. Soil volumetric water contents (VWC) in the CC and NCC plots were measured with soil water sensors. The sensors (TDR 315, Acclima, Meridian, ID, USA) were installed at depths of $15,30,46$, and $61 \mathrm{~cm}$. A data logger was set up for each sensor to measure and record hourly VWC at each depth. Soil VWC measurements at the four depths were interpreted using a weighted-average method to reflect the soil water conditions across the plant root zone [29]. The weight assigned to the sensor depth of $15,30,46$, and $61 \mathrm{~cm}$ was $0.3,0.25$, 0.25 , and 0.2 , respectively. The weighted-average VWC was used to determine the soil water depletion. An irrigation was generally triggered as the percentage of plant available water (PPAW) dropped to approximately 50\%. Using the weighted-average VWC, soil field capacity (FC), and permanent wilting point (PWP), the PPAW is defined as follows Equation (1):

$$
\text { PPAW }(\%)=\frac{(\text { Weighted_average VWC })-(\text { VWC at PWP })}{(\text { VWC at FC })-(\text { VWC at PWP })} \times 100 \%
$$

In irrigation scheduling, crop growth stage and short-time weather forecast were given consideration along with sensor-measured soil water contents. No irrigation was conducted in 2017 and 2019 due to sufficient precipitation in the summer. In 2018, $25 \mathrm{~mm}$ water was applied on 16 May after planting for better germination, and another $114 \mathrm{~mm}$ water was applied in six irrigation events from June to August with $19 \mathrm{~mm}$ depth of water in each irrigation to avoid runoff.

\subsection{Data Collection and Analysis}

In the three years, seed-cotton picked from the central rows of each plot were weighed for yield using a load cell weighing system installed on a cotton boll buggy. In 2017 and 2018, approximately $45 \mathrm{~kg}$ samples of seed-cotton were randomly collected from each plot during harvest and these samples were ginned using the micro-gin in USDA-ARS Cotton Ginning Research Unit for the lint turnout. In 2019, about $4 \mathrm{~kg}$ seed-cotton samples were randomly collected from each plot and ginned using a small saw-gin in USDA-ARS Crop Genetics Research Unit for lint turnout. Lint yield for each year was calculated using the area harvested, seed-cotton weight, and lint turnout. Soil water content variation in a CC plot and NCC plot for three years was recorded and processed for evaluating the impact of TRCC on soil water.

Proc ANOVA procedure of SAS (SAS Institute Inc., Cary, NC, USA) was used to determine the effect of $\mathrm{N}$ rate, $\mathrm{CC}$, and $\mathrm{N}$ rate $\times \mathrm{CC}$ on lint yield. Mean separation tests were performed at $p=0.05$ level using the PLM and Tukey's procedures of SAS.

\section{Results and Discussion}

\subsection{Cover Crop}

TRCC grew very well in spring 2017 (Figure 2). The average TRCC height was about $60 \mathrm{~cm}$. On average, the radish taproot was about $25 \mathrm{~cm}$ long and $5 \mathrm{~cm}$ in diameter. In 2018 and 2019, the cover crop did not grow as well as in 2017. The stalks were about $15-20 \mathrm{~cm}$ tall and the roots were about $10 \mathrm{~cm}$ long and $2 \mathrm{~cm}$ in diameter. One of the reasons for the poor growth of TRCC in these two seasons was that it suffered severe cold winter weather, which seriously damaged the plants and limited their growth in the subsequent spring seasons. 


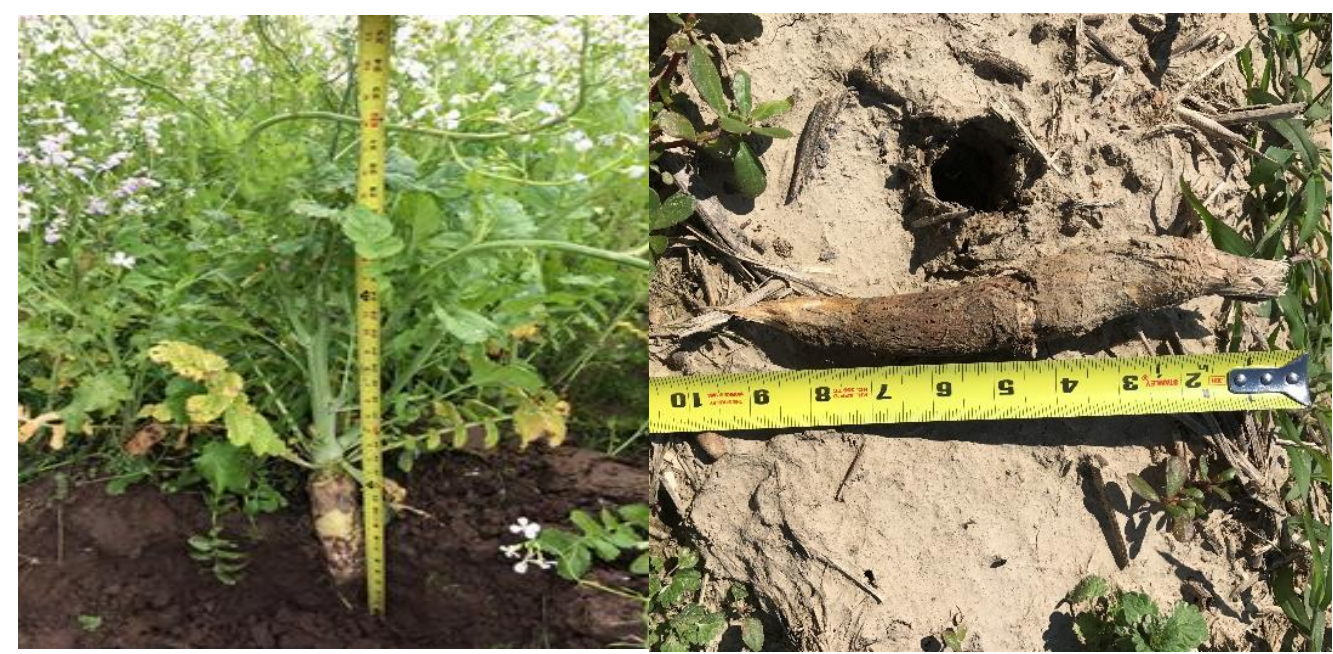

Figure 2. Tillage Radish cover crop in 2016-2017 winter season. Left: Biomass above ground surface and the root below ground surface. Right: Decomposed roots after the crop was killed for planting cotton.

As stated above, depending on the prior season cotton crop harvest, the TRCC was first planted on 12 October and replanted on 20 October in 2016, on 27 October in 2017, and on 25 October in 2018 for affecting cotton growth in 2017-2019 seasons, respectively. Figure 3 shows the air temperature variation, precipitation, and solar radiation from 2016 to 2019. The weather in the winters of 2017 and 2018 was colder and had more precipitation than the winter of 2016. From 1 October 2016 to 31 March 2017 there were 19 days with a temperature $<0{ }^{\circ} \mathrm{C}$ with a minimum temperature $\left(\mathrm{T}_{\min }\right)$ of $-9.4{ }^{\circ} \mathrm{C}$, and total precipitation was $608 \mathrm{~mm}$. However, from 1 October 2017 to 31 March 2018 there were 44 days with a temperature $<0{ }^{\circ} \mathrm{C}$ with a $\mathrm{T}_{\min }$ of $-13.3^{\circ} \mathrm{C}$, and total precipitation was $838 \mathrm{~mm}$. From 1 October 2018 to 31 March 2019, the number of days with a temperature $<0{ }^{\circ} \mathrm{C}$ was 33 while the $\mathrm{T}_{\min }$ was $-3.9^{\circ} \mathrm{C}$. Although the $\mathrm{T}_{\min }$ in 2019 winter was higher compared to the winter in 2017 and 2018, the total precipitation was $1071 \mathrm{~mm}$, which was much greater than that in the same period of the other two years.

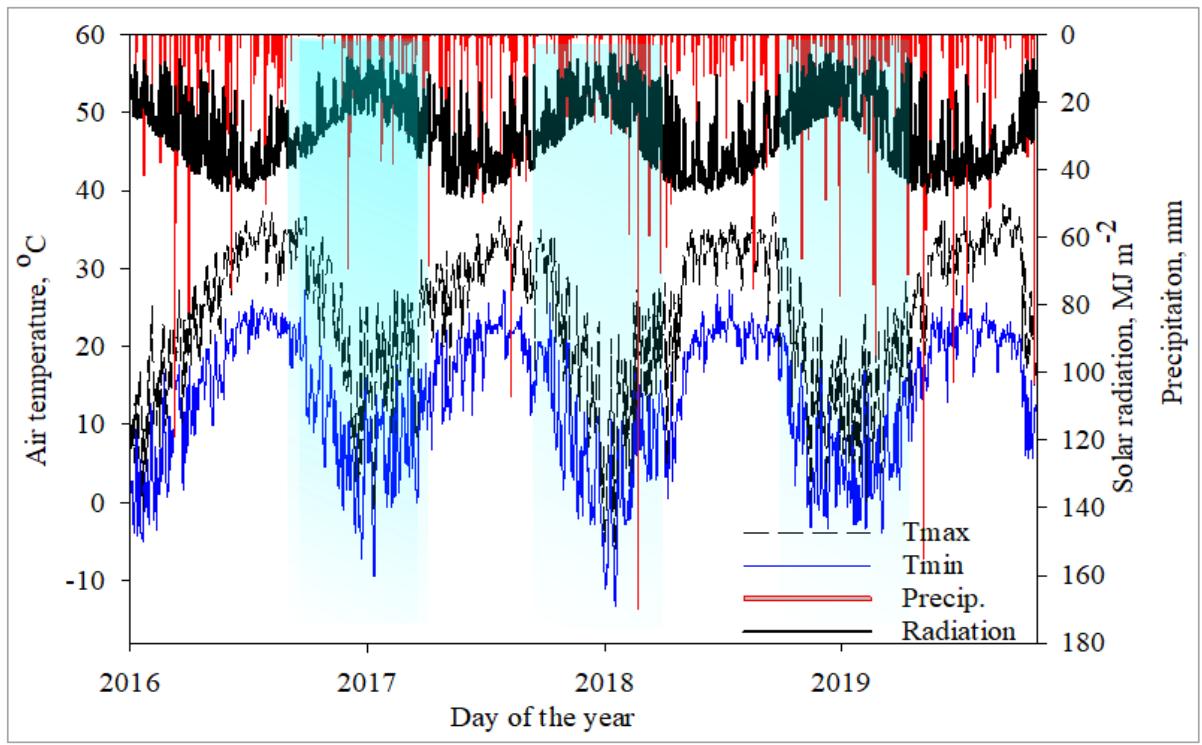

Figure 3. Daily maximum and minimum air temperatures, precipitation, and solar radiation from 1 January 2016 to 31 December 2019. Highlighted days are from 1 October to 31 March of each year in which TRCC grew. 
The earlier planting and subsequent mild weather helped in the establishment of the cover crop before severe winter set in for 2016, but the later plantings followed by severe winter in 2017 and 2018 severely restricted the establishment of the TRCC before winter started and its subsequent growth in the following springs. What we learned was that the TRCC should be planted no later than the middle of October to allow the plant to be well developed prior to the cold winter weather for its optimum regrowth in the subsequent spring. From the observed TRCC growth in 2016-2017 season, it is clear that a well-developed TRCC can survive the winter weather and grow fast in the following spring for optimum biomass, both above and underground (Figure 2). Further investigations for determining an optimum planting window and cutoff date for establishing TRCC in the climate of the MD regions is needed and will be taken up in subsequent studies.

\subsection{Soil Water}

The prime reason for choosing tillage radish as a cover crop was that TRCC can produce a large taproot swollen with carbohydrates and penetrate compacted soil to provide better soil tilth for cotton crop root growth in the following season (Figure 2). Such long and swollen roots filled with carbohydrates and other $\mathrm{N}$ containing metabolites, once killed in the spring season for planting cotton, can improve the soil fertility [30]. Furthermore, as the metabolites in the roots decompose, many holes left behind from the large taproots in the soil will allow more rainwater to infiltrate into the soil, which increases the soil water available for the cotton plant [20]. Cotton plants have a root system that can reach the water stored in deep soil profile [31]. It was hypothesized that the TRCC during the winter season that preceded the cotton season could possibly increase soil water availability for cotton root uptake, thereby reducing the need for supplemental irrigation for the crop [32]. Depending on the amount and distribution of the rainfall events, cover crops during the fallow season can improve water infiltration and reduce evapotranspiration and runoff losses [15-17].

We examined the soil water changes during the cotton growth season (summer) that can be attributed to the TRCC grown in the plots during the preceding winter season. Some increases in soil water content under cotton due to the TRCC were evident (Figure 4). Soil water content in plot 8 with TRCC was higher than soil water contents in plot 5 without TRCC consistently during the three cotton growth seasons (2017-2019). In Figure 4, the higher soil water content in plot 8 could be due to the increase of rainwater infiltration by TRCC of the soil and enhanced soil physical properties for retaining more water in the soil profile. Further investigations are needed for ascertaining the exact reason for the observed changes in water contents in the soil profile. The soil water content difference between the TRCC plot and the NCC plot was more pronounced in 2017 than similar effects measured in 2018 and 2019. This could be due to poor growth of the TRCC in these two years and resultant inability of these less-grown roots in generating significant increase in water infiltration to impact the soil water content. 

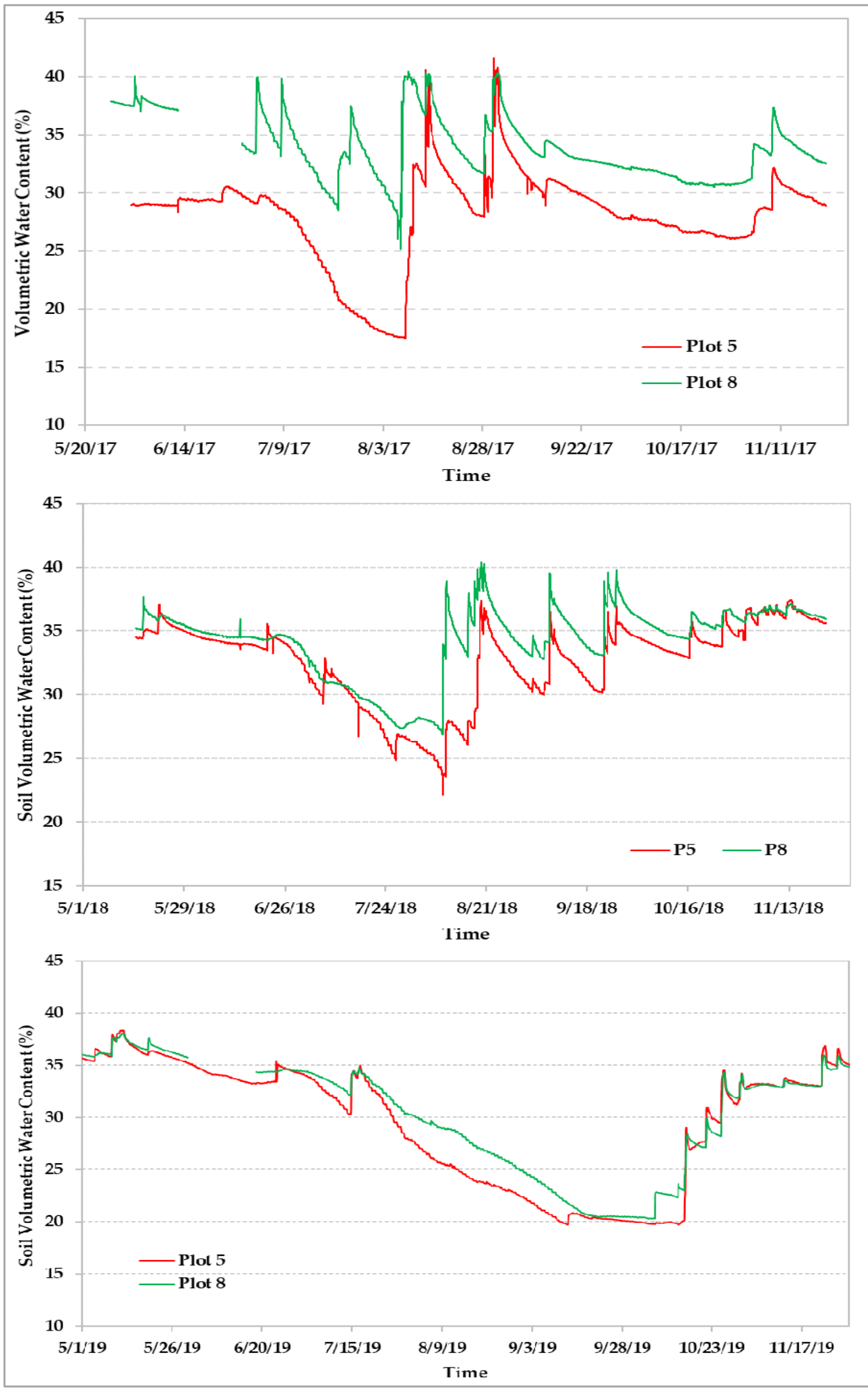

Figure 4. Soil water content variation in Plot 5 and Plot 8 during cotton growth season in 2017-2019. Plot 5 had no cover crop while Plot 8 had cover crop. Both plots had the same nitrogen application rate of $140 \mathrm{~kg} \mathrm{ha}^{-1}$. 


\subsection{Cotton Lint Yield}

Lint yield response to cover crop and $\mathrm{N}$ rate for the three-year trial are given in Tables 1 and 2. Cotton yield advantages from winter cover crops are expected in irrigated cotton production systems in the Southeast US regions [33]. ANOVA results indicated that in 2017 the effects of TRCC and N rate on lint yield were not significant, however, the effect of the interaction, $\mathrm{CC} \times \mathrm{N}$ rate on lint yield was significant $(p=0.0344)$ (Table 1). Treatment CC $\times$ N140 recorded the highest lint yield of $1328 \mathrm{~kg} \mathrm{ha}^{-1}$, which was significantly higher than the yield obtained in the treatment CC $\times$ N84 $(p=0.0240)$ and NCC $\times$ N140 $(p=0.0201)$ (Table 2). Although it was not statistically different, the yield in N140 was slightly higher than that in plots of N84, and yield in CC was slightly higher than that in NCC (Table 2).

Table 1. ANOVA summary for lint yield response to cover crop and nitrogen application rates.

\begin{tabular}{cccccc}
\hline Year & Source & DF & Mean Square & F Value & Pr $>$ F \\
\hline \multirow{2}{*}{2017} & Cover Crop & 1 & 2408 & 2.39 & 0.1607 \\
& N rate & 1 & 1925 & 1.91 & 0.2042 \\
& Cover Crop $\times$ N rate & 1 & 6533 & 6.48 & 0.0344 \\
\multirow{2}{*}{2018} & Cover Crop & 1 & 9690 & 0.69 & 0.4309 \\
& N rate & 1 & 32137 & 2.28 & 0.1694 \\
& Cover Crop $\times$ N rate & 1 & 3234 & 0.23 & 0.6447 \\
& Cover Crop & 1 & 31416 & 2.75 & 0.1361 \\
& N rate & 1 & 90828 & 7.94 & 0.0226 \\
& Cover Crop $\times$ N rate & 1 & 4563 & 0.4 & 0.5453 \\
\hline
\end{tabular}

$\mathrm{N}$ = nitrogen; $\mathrm{DF}$ = degree of freedom; $\mathrm{Pr}$ = probability; F = Fisher statistic.

Table 2. Lint yield means $\left(\mathrm{kg} \mathrm{ha}^{-1}\right)$ and mean comparison of various treatments.

\begin{tabular}{|c|c|c|c|c|c|c|c|}
\hline \multirow{2}{*}{ Effect } & \multirow{2}{*}{ Comparison } & \multicolumn{2}{|c|}{2017} & \multicolumn{2}{|c|}{2018} & \multicolumn{2}{|c|}{2019} \\
\hline & & Mean * & SD & Mean & SD & Mean & SD \\
\hline $\mathrm{CC}$ & \multirow{2}{*}{ CC-NCC } & $1292^{\mathrm{e}}$ & 54 & $1429^{\mathrm{e}}$ & 100 & $983^{e}$ & 148 \\
\hline NCC & & $1264^{\mathrm{e}}$ & 20 & $1486^{\mathrm{e}}$ & 140 & $1085^{\mathrm{e}}$ & 124 \\
\hline N84 & \multirow{2}{*}{ N84-N140 } & $1266^{\mathrm{e}}$ & 27 & $1405^{\mathrm{e}}$ & 118 & $947^{\mathrm{a}}$ & 123 \\
\hline N140 & & $1291^{\mathrm{e}}$ & 52 & $1509^{\mathrm{e}}$ & 105 & $1121^{b}$ & 102 \\
\hline $\mathrm{CC} \times \mathrm{N} 84$ & \multirow{2}{*}{$\mathrm{CC} \times \mathrm{N} 84-\mathrm{CC} \times \mathrm{N} 140$} & $1256^{\mathrm{a}}$ & 39 & $1393^{\mathrm{e}}$ & 109 & $876^{\mathrm{e}}$ & 137 \\
\hline $\mathrm{CC} \times \mathrm{N} 140$ & & $1328^{b}$ & 43 & $1464^{\mathrm{e}}$ & 97 & $1089^{\mathrm{e}}$ & 45 \\
\hline $\mathrm{NCC} \times \mathrm{N} 84$ & \multirow{2}{*}{$\mathrm{NCC} \times \mathrm{N} 84-\mathrm{NCC} \times \mathrm{N} 140$} & $1275^{\mathrm{e}}$ & 9 & $1417^{\mathrm{e}}$ & 151 & $1018^{\mathrm{e}}$ & 61 \\
\hline $\mathrm{NCC} \times \mathrm{N} 140$ & & $1253^{\mathrm{e}}$ & 23 & $1554^{\mathrm{e}}$ & 111 & $1153^{\mathrm{e}}$ & 145 \\
\hline $\mathrm{CC} \times \mathrm{N} 84$ & \multirow{2}{*}{$\mathrm{CC} \times \mathrm{N} 84-\mathrm{NCC} \times \mathrm{N} 84$} & $1256^{\mathrm{e}}$ & 39 & $1393^{\mathrm{e}}$ & 109 & $876^{\mathrm{e}}$ & 137 \\
\hline $\mathrm{NCC} \times \mathrm{N} 84$ & & $1275^{\mathrm{e}}$ & 9 & $1417^{\mathrm{e}}$ & 151 & $1018^{\mathrm{e}}$ & 61 \\
\hline $\mathrm{CC} \times \mathrm{N} 140$ & \multirow{2}{*}{$\mathrm{CC} \times \mathrm{N} 140-\mathrm{NCC} \times \mathrm{N} 140$} & $1328^{c}$ & 43 & $1464^{\mathrm{e}}$ & 97 & $1089^{\text {e }}$ & 45 \\
\hline $\mathrm{NCC} \times \mathrm{N} 140$ & & $1253^{d}$ & 23 & $1554^{\mathrm{e}}$ & 111 & $1153^{\mathrm{e}}$ & 145 \\
\hline
\end{tabular}

${ }^{*}$ Means with different letters $(\mathrm{a}, \mathrm{b}, \mathrm{c}, \mathrm{d}, \mathrm{e})$ of same comparison in same column are significantly different $(p<0.05) . \mathrm{N}=$ nitrogen; $\mathrm{CC}=$ cover crop; $\mathrm{NCC}=$ no cover crop; $\mathrm{SD}=$ standard deviation .

In 2018, effect of $\mathrm{N}$ rate, cover crop, and CC $\times \mathrm{N}$ rate on yield was not significant, with $p$ values of $0.4309,0.1694$, and 0.6447 , respectively (Table 1 ). NCC $\times$ N140 had the maximum yield of $1554 \mathrm{~kg} \mathrm{ha}^{-1}$, and CC $\times \mathrm{N} 84$ had the minimum yield of $1393 \mathrm{~kg} \mathrm{ha}^{-1}$ (Table 2). Yield in NCC was $57 \mathrm{~kg} \mathrm{ha}^{-1}$ higher than in CC, and the yield in N140 was $104 \mathrm{~kg} \mathrm{ha}^{-1}$ higher than in N84. Although no significant effect of cover crop and N rate on yield was observed in 2018, the results showed that $\mathrm{N}$ application rate of $140 \mathrm{~kg} \mathrm{ha}^{-1}$ increased the yield while cover crop reduced the yield (Table 2).

In 2019, the ANOVA indicated that effect of $\mathrm{N}$ rate on lint yield was significant $(p=0.0226)$ while the effects of CC $(p=0.1361)$ and CC $\times \mathrm{N}$ rate $(p=0.5453)$ on lint yield were not (Table 1). Lint yield in N140 was significantly higher than in N84 $(p<0.05)$ (Table 2). The yield in NCC was $10.4 \%$ higher than CC while the yield of CC $\times$ N140 was 
$24.3 \%$ higher than the yield of CC $\times$ N84. However, these differences were not statistically significant $(p>0.05)$ (Table 2). In a no-till system in Alabama, Southeast USA, cotton yield following rye (Secale cereale L.) cover crop was significantly higher than crimson clover used as cover crop [33]. Cotton lint yield following a wheat (Triticum aestivum L.) also increased significantly [34]. Their studies showed the importance of choosing the right cover crop suited for the climate and soil of the location for tapping the positive benefits of cover crop on cotton yields. Results of our three-year trial indicated that TRCC did not significantly enhance cotton yields in the humid climate of the Mississippi Delta. This could be due to the high inputs of water (Figure 3; rainfall and irrigations) and high rates of $\mathrm{N}$ neutralizing the positive contributions to cotton growth expected from the cover crops in these aspects in the trials. Sub-optimum winter temperatures hampered the establishment and subsequent growth of the cover crop, possibly contributing to its minimum impacts on cotton crop performance in the following season (Figure 3).

Increasing $\mathrm{N}$ rate from 84 to $140 \mathrm{~kg} \mathrm{ha}^{-1}$ increased the yield by $2 \%, 7.4 \%$, and $18.4 \%$ in 2017, 2018, and 2019, respectively. Farmer-received cotton lint price was $1.51 \mathrm{USD} \mathrm{kg}^{-1}$, $1.55 \mathrm{USD} \mathrm{kg}^{-1}$, and $1.29 \mathrm{USD} \mathrm{kg}^{-1}$ in 2017, 2018, and 2019, respectively [35]. Using the cotton price and $\mathrm{N}$ cost in each year, economic gain by increasing the $\mathrm{N}$ rate was calculated to be 103 USD ha $^{-1}$ and 166 USD ha $^{-1}$ in 2018 and 2019, respectively. However, the gain was negative $20 \mathrm{USD} \mathrm{ha}^{-1}$ in 2017 due to small yield increase. The net profit increase not only depended on the increase of yield, but also the price of cotton and $\mathrm{N}$ fertilizer in each year. For example, the cotton price decreased 17\% from 2018 to 2019 while the N price increased $7 \%$, which generate substantial influence on the net profit offered by the increase of $\mathrm{N}$ rate.

In general, the 3-year results showed that, compared to $\mathrm{N}$ rate of $84 \mathrm{~kg} \mathrm{ha}^{-1}$, the $\mathrm{N}$ rate of $140 \mathrm{~kg} \mathrm{ha}^{-1}$ could increase lint yield while the cover crop could decrease the lint yield. However, yield response to cover crop and N rate in 2017 did not follow that trend well. In 2017, CC treatment had a higher yield than NCC while it was reversed in both 2018 and 2019 season. Prior to 2017, this field was used for another study on N fertilization in cotton. The yield responding differently in 2017 could be caused by the $\mathrm{N}$ residual left in the field in the previous season, which was picked up by the TRCC and grew well to its potential as indicated by the significant results in cover crop by $\mathrm{N}$ rate interaction $(p<0.0344)$ (Table 1$)$. The residual $\mathrm{N}$ unused by the previous crop and left in the soil was available for use by the TRCC in fall of 2016 and spring of 2017. The healthy TRCC (Figure 2) scavenged the residual N [20], which allowed cotton yield in 2017 to respond to the additional $\mathrm{N}$ applied. The stunted TRCC in the other two years did not use as much residual nitrogen, possibly resulting in the non-significant effect of CC $\times$ N rate on lint yield in $2018(p=0.6447)$ and $2019(p=0.5453)($ Table 1$)$.

\section{Conclusions}

Response of cotton yield and soil water content to nitrogen application rates and tillage radish cover crop (TRCC) in cotton was investigated. Results showed that the TRCC had no significant effect on cotton yield. Increasing $\mathrm{N}$ rate from $84 \mathrm{~kg} \mathrm{ha}^{-1}$ to $140 \mathrm{~kg} \mathrm{ha}^{-1}$ increased cotton yield in one out of three years in the experiments. Interaction between cover crop and nitrogen rate on cotton yield was significant only in one out of the three years. Our study indicated that TRCC increased soil water infiltration capacity and benefited the soil to retain higher soil water content. Increasing $N$ rate from $84 \mathrm{~kg}$ $\mathrm{ha}^{-1}$ to $140 \mathrm{~kg} \mathrm{ha}^{-1}$ could possibly increase cotton yield but needs further investigations to confirm. The non-significant impact of TRCC on cotton yield could be caused by poor growth of TRCC from cold temperatures and excessive winter rains.

Author Contributions: Conceptualization, R.S. and S.S.A.; data analysis, R.S.; writing, R.S.; editing, S.S.A. All authors have read and agreed to the published version of the manuscript. 
Funding: This research was supported by the U.S. Department of Agriculture, Agricultural Research Service. Cotton Inc. provided partial financial support to this project (Cooperative Agreement No.: 58-6066-7-077, 58-6066-8-019 and 58-6066-9-020).

Institutional Review Board Statement: Not applicable.

Informed Consent Statement: Not applicable.

Data Availability Statement: Not applicable.

Acknowledgments: The authors would like to thank Jonnie Baggard and RoYesia Gray for their technical support in this project.

Conflicts of Interest: The authors declare no conflict of interest regarding the publication of this paper.

Disclaimer: Mention of trade names or commercial products in the 'Materials and Methods' section in this article is solely for the purpose of providing specific information and does not imply recommendation or endorsement by the U.S. Department of Agriculture (USDA). USDA is an equal opportunity provider and employer.

\section{References}

1. U.S. Department of Agriculture (USDA). Economic Research Service. Cotton and Wool: Overview. 2020. Available online: https:/ / www.ers.usda.gov/topics/crops/cotton-wool/ (accessed on 3 February 2021).

2. Bauer, P.J.; Roof, M.E. Nitrogen, aldicarb, and cover crop effects on cotton yield and fiber properties. Agron. J. 2004, 96, 369-376. [CrossRef]

3. Girma, K.; Teal, R.K.; Freeman, K.W.; Boman, R.K.; Raun, W.R. Cotton lint yield and quality as affected by applications of N, P, and $\mathrm{K}$ fertilizers. J. Cotton Sci. 2007, 11, 12-19.

4. Fernandez, C.J.; McInnes, K.J.; Cothren, J.T. Water status and leaf area production in water- and nitrogen stressed cotton. Crop Sci. 1996, 36, 1224-1233. [CrossRef]

5. Gerik, T.J.; Oosterhuis, D.M.; Torbert, H.A. Managing cotton nitrogen supply. Adv. Agron. 1998, 64, $115-147$.

6. Sui, R.; Byler, R.K.; Delhom, C.D. Effect of nitrogen application rate on yield and quality in irrigated and rainfed cotton. J. Cotton Sci. 2017, 21, 113-121.

7. Gerik, T.J.; Jackson, B.S.; Stockle, C.O.; Rosenthal, W.D. Plant nitrogen status and boll load of cotton. Agron. J. 1994, 86, 514-518. [CrossRef]

8. Cisneros, J.J.; Godfrey, L.D. Mid-season pest status of the cotton aphid (Homoptera: Aphididae) in California cotton: Is nitrogen a key factor? Environ. Entomol. 2001, 30, 501-510. [CrossRef]

9. Howard, D.D.; Gwathmey, C.O.; Essington, M.E.; Roberts, R.K.; Mullen, M.D. Nitrogen fertilization of no-till cotton on loessderived soils. Agron. J. 2001, 93, 157-163. [CrossRef]

10. Tewolde, H.; Fernandez, C.J. Vegetative and reproductive dry weight inhibition in nitrogen- and phosphorus-deficient Pima cotton. J. Plant Nutr. 1997, 20, 219-232. [CrossRef]

11. Van Groenigen, J.W.; Huygens, D.; Boeckx, P.; Kuyper, T.W.; Lubbers, I.M.; Rütting, T.; Groffman, P.M. The soil N cycle: New insights and key challenges. Soil 2015, 1, 235-256. [CrossRef]

12. Khan, A.; Tan, D.K.Y.; Afridi, M.Z.; Luo, H.; Tung, S.A.; Ajab, M.; Fahad, S. Nitrogen fertility and abiotic stresses management in cotton crop: A review. Environ. Sci. Pollut. Res. 2017, 24, 14551-14566. [CrossRef] [PubMed]

13. Snipes, C.; Nichols, S.P.; Poston, D.H.; Walker, T.W.; Evans, L.P.; Robinson, H.R. Current Agricultural Practices of the Mississippi Delta; Mississippi Agricultural \& Forestry Experiment Station, Bulletin 1143; Mississippi State University: Mississippi State, MS, USA, 2005; p. 21.

14. Clark, B.R.; Hart, R.M.; Gurdak, J.J. Groundwater Availability of the Mississippi Embayment: U.S; Geological Survey Professional Paper 1785; US Geological Survey: Reston, VA, USA, 2011; 62p.

15. Unger, P.W.; Vigil, M.F. Cover crop effects on soil water relationships. J. Soil Water Conserv. 1998, 53, $200-207$.

16. Dabney, S.M.; Delgado, J.A.; Reeves, D.W. Using winter cover crops to improve soil and water quality. Commun. Soil Sci. Plant Anal. 2001, 32, 1221-1250. [CrossRef]

17. Kaspar, T.C.; Kladivko, E.J.; Singer, J.W.; Morse, S.; Mutch, D.R. Potential and limitations of cover crops, living mulches, and perennials to reduce nutrient losses to water sources from agricultural fields in the upper Mississippi River Basin. In UMRSHNC (Upper Mississippi River Sub-basin Hypoxia Nutrient Committee). Final Report: Gulf Hypoxia and Local Water Quality Concerns Workshop; ASABE: St. Joseph, MI, USA, 2008; pp. 127-148.

18. Zablotowicz, R.M.; Reddy, K.N.; Krutz, L.J.; Gordon, R.E.; Jackson, R.E.; Price, L.D. Can leguminous cover crops partially replace nitrogen fertilization in Mississippi Delta cotton production? Int. J. Agron. 2011, 2011, 135097. [CrossRef]

19. Nouria, A.; Leea, J.; Yin, X.; Tylerc, D.D.; Saxtond, A.M. Thirty-four years of no-tillage and cover crops improve soil quality and increase cotton yield in Alfisols, Southeastern USA. Geoderma 2019, 337, 998-1008. [CrossRef] 
20. Weil, R.R.; White, C.M.; Lawley, Y. Forage Radish: New Multi-Purpose Cover Crop for the Mid-Atlantic. Fact Sheet 824 . Maryland Cooperative Extension, University of Maryland 2009. Available online: https://www.researchgate.net/publication/233861705_ Forage_radish_A_New_Multi-Purpose_Cover_Crop_for_the_Mid-Atlantic (accessed on 27 January 2021).

21. Chen, G.; Weil, R.R. Penetration of cover crop roots through compacted soils. Plant Soil 2010, 331, 31-43. [CrossRef]

22. Goolsby, D.A.; Battaglin, W.A. Long-term changes in concentrations and flux of nitrogen in the Mississippi River Basin, USA. Hydrol. Process 2001, 15, 1209-1226. [CrossRef]

23. Potter, A.R.; Atwood, J.D.; Goss, D.W. Modeling regional and national non-point source impacts from US agriculture. ASAE Paper No. 012191. In Proceedings of the 2001 ASAE Annual Meeting, Sacramento, CA, USA, 30 July-1 August 2001. [CrossRef]

24. Bakhsh, A.; Kanwar, R.S.; Bailey, T.B.; Cambardella, C.A.; Karlen, D.L.; Colvin, T.S. Cropping system effects on NO3-N loss with subsurface drainage water. Trans. ASAE 2002, 45, 1789-1797. [CrossRef]

25. NRCS (Natural Resources Conservation Service). United States Department of Agriculture. Web Soil Survey 2021. Available online: https: / / websoilsurvey.sc.egov.usda.gov/ (accessed on 8 March 2021).

26. Catchot, A. 2016 Insect Control Guide for Agronomic Crops. Mississippi State University Ext. Service 2015. Publ. 2471. Available online: https:/ / www.mississippi-crops.com/2015/12/16/2016-insect-control-guide-now-available/ (accessed on 19 March 2021).

27. Mississippi Weed Science Committee (MWSC). 2016 Weed Control Guidelines for Mississippi. Mississippi State University Ext. Service 2016, Publ. 1532. Available online: http:/ / extension.msstate.edu/publications/weed-control-guidelines-for-mississippi (accessed on 19 March 2021).

28. Bond, J.A.; Dodds, D.M.; Golden, B.R.; Irby, J.T.; Larson, E.J.; Lawrence, B.H.; Sarver, J.M. 2018 Weed Management Suggestions for Mississippi Row Crops 2017, Publ. 3171. Available online: https://www.mssoy.org/uploads / files/weed-cont-guide-misssoy-2018_1.pdf (accessed on 19 March 2021).

29. Sui, R. Irrigation scheduling using soil moisture sensors. J. Agric. Sci. 2018, 10, 1-11. [CrossRef]

30. Lewis, K.L.; Burke, J.A.; Keeling, W.S.; McCallister, D.M.; DeLaune, P.B.; Keeling, J.W. Soil benefits and yield limitations of cover crop use in Texas High Plains cotton. Agron. J. 2018, 110, 1616-1623. [CrossRef]

31. Chen, G.; Weil, R.R.; Hill, R.L. Effects of compaction and cover crops on soil least limiting water range and air permeability. Soil Tillage Res. 2014, 136, 61-69. [CrossRef]

32. Haruna, S.I.; Nkongolo, N.; Anderson, S.H.; Eivazi, F. In situ infiltration as influenced by cover crop and tillage management. J. Soil Water Conserv. 2018, 73, 164-172. [CrossRef]

33. Kornecki, T.S.; Price, A.J.; Balkcom, K.S. Cotton population and yield following different cover crops and termination practices in an Alabama no-till system. J. Cotton Sci. 2015, 19, 375-386.

34. McDonald, M.D.; Lewis, K.L.; Ritchie, G.L. Short term cotton lint yield improvement with cover crop and no-tillage implementation. Agronomy 2020, 10, 994. [CrossRef]

35. USDA Agricultural Marketing Service. Cotton Price Stat. 2021, 102, 11. 